\title{
Japan aims high for growth
}

\section{Innovation in science is at the heart of government plans to boost the economy.}

\section{BY DAVID CYRANOSKI}

$\mathrm{T}$ he Japanese government is working on a plan to revitalize its science workforce by boosting opportunities for female scientists, attracting top talent from abroad and increasing the commercialization of research. So what else is new? Over the past decade, successive administrations have had similar goals, but little progress has been made. This time, analysts and scientists think that things might be different.

Prime Minister Shinzo Abe is riding high since his Liberal Democratic Party swept back to power in December. He has stimulated the economy, ending 15 years of deflation, jumpstarted the stock market and weakened the yen to spur exports. His reform platform includes a new growth strategy, and central to that strategy is innovation in science and technology.

Abe's cabinet has already committed hundreds of billions of yen to space, physics and stemcell research, in a stimulus package announced in January. But more aggressive measures are yet to come. On 17 May, the Council for Science and Technology Policy — the nation's leading science body, which Abe chairs - released the first draft of a Comprehensive Science, Technology and Innovation Strategy, calling for even more fundamental changes.

To be finalized by the end of this year, the strategy includes eye-catching targets for bolstering the country's intellectual base. It calls for $30 \%$ of new recruits at research institutes and universities to be female by 2016, up from $21.2 \%$ in 2010. And faced with fewer university graduates and a shrinking birth rate, Japan is looking to open itself up to foreigners. Under the plan, international researchers would occupy $20 \%$ of staff positions at leading research organizations by 2020 , and $30 \%$ by 2030 . That would be an ambitious jump from the 2010 figure of $3.9 \%$.

To increase technology transfer, the plan sets a goal of doubling the number of collaborations worth more than 10 million yen (US\$98,000) between university and industry by 2030 . And it calls for the numbers of foreign patent applications and collaborations lasting more than 3 years to similarly double.

Japan needs to make up ground. It has lost the competitive edge it once had over China, South Korea and other Asian rivals in industries such as microelectronics and pharmaceuticals. "Over the past decade, Japan has been stagnant in terms of innovation," says Yuko Ito, head of the Science, Technology and Innovation Policy division at the Tokyo-based

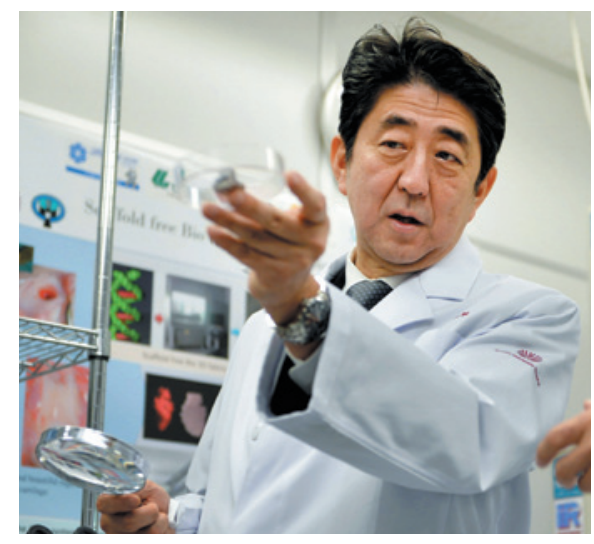

Japan's Prime Minister Shinzo Abe visits a lab in Fukuoka.

National Institute of Science and Technology Policy.

Abe failed to reverse those trends in 2006, during his first term as prime minister, with a largely ineffectual 'Innovation 25' programme. Nonetheless, some see reasons for optimism, not only about economic success but also for a more innovative workforce. The strategy this time "is emphasizing the need for cultivating human resources, especially women”, says Ito.

Hisako Ohtsubo, a molecular biologist at Nihon University near Funabashi who researches gender equality in science, is also cautiously optimistic. She says that it was a pleasant surprise to hear Abe - a conservative who, for example, opposes passage of the imperial throne to the female blood line - repeatedly mention the importance of increasing women's role in the business world. Most startling for Ohtsubo was Abe's statement that childcare across Japan should be expanded, something many analysts have said is crucial for women's ability to have careers in research and other sectors. "He's a different phenotype," she says. "Before he would never have talked about such things."

Still, she is waiting to see whether Abe will follow up his words with the necessary investment in programmes to give extra grants to women and encourage companies and universities to hire women to senior researcher positions, and not just as regular staff. "That's the only way we will be able to overcome the deeply embedded stereotypes in the system," Ohtsubo says.

Piero Carninci, a genomics expert based in Yokahama at the RIKEN Center for Life Science Technologies with nearly two decades' experience in Japan, has advice for Abe if he is serious about courting foreigners. As head of RIKEN's new Division of Genomic Technologies, he is the first foreigner to hold a division director position. The top-down management style of mentors, communication problems in the laboratory and the Japanese lifestyle can all be daunting for people from abroad, he says.

Carninci's remedy includes giving foreign researchers academic independence and reasonable start-up budgets, as well as assistance in overcoming language problems. Also key: offering an equal opportunity with Japanese nationals to climb the career ladder.

Atsushi Sunami, a science-policy expert at the National Graduate Institute for Policy Studies in Tokyo, says that efforts to hire overseas talent may also benefit from one of the themes of the government's growth strategy: deregulation of markets and quasi-governmental organizations, including universities.

Decisions on the main budget items still have to be made, Sunami says. A proposal in the comprehensive strategy would give an annual budget - some 50 billion yen, according to Sunami - to the Council for Science and Technology Policy to fund science. Currently, the council is only an advisory body. But until the budget decisions are made, Sunami says, the strategy is "just a piece of paper".

Koichi Sumikura of the National Institute of Science and Technology Policy thinks that the Fukushima nuclear disaster, and the ensuing energy shortages, should help to keep innovation on the agenda. "The disaster is what really makes things different this time," says Sumikura. "Before, politicians talked about innovation without indicating any real direction. Now there is a clear need to recover from the disaster and build a stronger society." - SEE EDITORIAL P.535

\section{CORRECTIONS}

The world map in 'GM crops: A story in numbers' (Nature 497, 22-23; 2013) wrongly highlighted Slovenia instead of Slovakia as one of Europe's GM-cropproducing nations. The table in the News story 'Log-jam in agency confirmations' (Nature 497, 418-419; 2013) omitted Christine Todd Whitman's full name. In the News story 'Graphene knock-offs probe ultrafast electronics' (Nature 497, 422-423; 2013), reference 2 should have cited volume 438, not 483. And the News Feature 'Outward bound' (Nature 497, 424-427; 2013) wrongly stated that Voyager 1 and Voyager 2 were renamed en route to Jupiter. In fact, they were renamed before launch. 